\title{
Shelf Life Assessment of Functional (Antioxidant Added Low Fat-Low Sodium) Chevon Patties under Refrigeration
}

\author{
N.K. Nayak ${ }^{1 *}$, V. Pathak ${ }^{2}$, M. Goswami ${ }^{2}$ and S.K. Bharti ${ }^{2}$ \\ ${ }^{1}$ Department of Livestock Products Technology, College of Veterinary Science \& A.H., Mhow, \\ Indore (453446), M.P., India \\ ${ }^{2}$ Department of Livestock Products Technology, College of Veterinary Science \& A.H., \\ DUVASU, Mathura, U.P., India \\ *Corresponding author
}

The chevon patties were developed to increase the functional value with decreasing fat and sodium content. carrageenan and different salt variant of $\mathrm{NaCl}, \mathrm{KCl}, \mathrm{CaCl}_{2}$ and Mushroom extract were used in different combination and then selected variant was added with Noni as natural antioxidant and finally patties $0.6 \%$ carrageenan, proportionate blend of $\mathrm{NaCl}$, $\mathrm{KCl}$, and $\mathrm{CaCl}_{2}$ and $3 \%$ noni as antioxidants was found superior and most acceptable by the sensory panelists, hence, selected for further storage stability under refrigeration. The $\mathrm{pH}, \mathrm{TBA}, \mathrm{FFA}$, peroxide value and microbial counts of functional chevon patties was significantly $(\mathrm{P}<0.0 .5)$ lower as compared to control during storage. With the advancement of storage time these were increased significantly $(\mathrm{P}<0.05)$. However, rate of oxidation in functional chevon patties were considered lower than control as evidenced in estimated value of FFA and PV. Functional chevon patties showed significantly $(\mathrm{P}<0.05)$ higher scores for flavor, juiciness and texture from $12^{\text {th }}$ day of storage period. Gradual decreases in all sensory attributes were noticed during storage, however, significantly $(\mathrm{P}<0.05)$ higher scores in functional chevon patties as compared to control was observed throughout the storage. From the study it was concluded that the developed low fat low sodium enriched with antioxidants chevon patties may be considered as health full functional product which was very well accepted up to 15 day under refrigeration.

\section{Introduction}

Goat meat is one of the most consumed red meats worldwide. The demand for goat meat is on the rise. The increase was mainly due to the growth of ethnic populations and also the awareness of health conscious consumers of lower fat in chevon compared to other red meats. Growing understanding of the relationship between diet and health is leading to new insights into the effect of food ingredients on physiological function and health, inducing increased consumers demand for healthy, nutritious foods with additional health promoting functions, such as functional foods. Over the last several decades, meat 
products have come under increasing scrutiny by medical, nutritional and consumer groups because of the associations established between their consumption (Low fat and cholesterol) and the risk of some of the major degenerative and chronic diseases (heart disease, cancer, hypertension and obesity). Therefore, meat-based functional foods are being seen as an opportunity to improve the "image" of meat and address consumers' needs and also to update the nutritional and dietary goals (Jimenez-Colmenero, F., 2007a). Most researches into meat-based functional foods are confined to animal production or technological strategies for increasing the presence of healthy compounds (Brian et al., 2012). The functional food should "contain a component with a selective effect on one or various functions of the organism whose positive effects can be justified as functional (physiological) or even healthy". Lipid oxidation is of great concern to the consumer because it causes physical and chemical deterioration of food quality, such as undesirable changes in taste, texture, appearance and development of rancidity, losses of important nutritional values and formation of potentially harmful components including free radicals and reactive aldehydes (Conde et al., 2011). Recent investigation has focused towards identification of novel antioxidants from natural sources. Due to their high content of phenolic compounds, fruits and other plant materials are regarded as a good source of natural antioxidants which provide an alternative to currently used conventional antioxidants (Nunez de et al., 2008). Several scientists throughout the globe have explored to increase functionality of meat products by incorporating antioxidants and reducing fat and salt content to improve the health of the consumer. However, there is a wide gap in research and development of such products in Indian subcontinent. Looking to the facts and overcome the problem associated with health of consumer the present study was aimed with the objective of shelf life assessment of functional (antioxidant added low fat-low sodium) chevon patties under refrigeration.

\section{Materials and Methods}

\section{Meat and additives}

Goat meat required for the experiments was procured from authorized retail meat shop. The meat was obtained from hind legs of carcasses of good conformation of nondescript adult male goats slaughtered according to traditional halal method. The required quantity was purchased within $2-3 \mathrm{~h}$ of slaughter, packed in low-density polyethylene (LDPE) bags and brought to the laboratory within $20 \mathrm{~min}$. The meat was deboned, trimmed-off separable fat and connective tissue. The samples were kept for conditioning in a refrigerator at $4 \pm 1{ }^{\circ} \mathrm{C}$ for 6-8 $\mathrm{h}$ and then frozen at $-18{ }^{\circ} \mathrm{C}$ till further use. The samples were used after partial thawing for $15 \mathrm{~h}$ at $4{ }^{\circ} \mathrm{C}$. Various Flours, condiments (onion, ginger, and garlic), oil, salt, gram hulls were purchased from standard shop of local market. The composition of spice mix is given in Table 1 . The ingredients in desired ratio were procured from local market, dried at $45 \pm 2^{\circ} \mathrm{C}$ for 2 hours followed by grinding and sieving through 100 mesh. The spice mix was stored in low density polyethylene bags and used as per requirement. All the chemicals and media used in the study were of analytical grade and obtained from standard firm.

\section{Processing}

Chevon meat was obtained from thigh muscle from 9-11 month of aged male animals lean meat was cut into smaller chunks and minced in a Sirmen mincer (MOD- TC 32 R10 U.P. INOX, Marsango, Italy) with $6 \mathrm{~mm}$ plate followed by common grind size, the $4 \mathrm{~mm}$ 
plate. The common salt, vegetable oil, refined wheat flour (maida), sodium tripolyphosphate, spice mixture and condiment mix were added to weighed meat according to formulation. Meat emulsion for patties was prepared in Bowl Chopper [MOD C 15 2.8G 4.0 HP, Marsango, Italy]. Minced meat was blended with salt and sodium tripolyphosphate for 1.5 minute. Water in the form of crushed ice was added and blending continued for 1 minute. This was followed by addition of refined vegetable oil and blended for another 1 to 2 minutes. This was followed by addition of spice mixture, condiments and other ingredients and again mixed for 1.5 to 2 minutes to get the desired emulsion. Adequate care was taken to keep the end point temperature below $18^{0} \mathrm{C}$ by preparing the emulsion in cool hours of morning, by addition of meat and other ingredients in chilled/partially thawed form and by addition of crushed ice or ice water. The emulsion were prepared in two different groups as per given formulation (Table 2). About $50 \mathrm{~g}$ of emulsion was moulded on steel plate with circular ring $(55 \mathrm{~mm}$ diameter and $20 \mathrm{~mm}$ height). The height and diameter of the patty was determined by Vernier Callipers. Patties were cooked in a pre-heated convection oven at $180^{\circ} \mathrm{C}$ for 14 minutes after which they were turned and allowed to get cooked for 4 more minutes till internal temperature reached about $75^{\circ} \mathrm{C}$ (Probe thermometer, Labware Scientific, Inc, USA). The patties were packed in low-density polyethylene pouches and stored at refrigerated temperature $\left(4 \pm 1^{\circ} \mathrm{C}\right)$.

\section{Packaging materials}

Low density Polyethylene (LDPE) bags of 250 gauge thickness were sourced from local market for packaging and were pre-sterilized by exposing to U.V. light for 30 minutes before use.

\section{Physicochemical analysis}

Prior to measurement, $\mathrm{pH}$ meter was calibrated every time as per the manufacturer's instructions using known buffers of $\mathrm{pH} 7.0$ and 4.01. Reading was taken twice for each sample and average of reading was taken as $\mathrm{pH}$ of sample.TBA value was estimated as per procedure given by Tarladgis et al., (1960). Free fatty acid value was determined by the prescribed method (Koniecko, 1979)

The peroxide value was measured as per procedure given by A.O.C.S (1992) with suitable modifications. Five gram of sample was blended with $30 \mathrm{ml}$ acetic acid and chloroform solution (3:2) in $250 \mathrm{ml}$ glass stoppered Erlenmeyer flask. Slurry obtained was gently swirled to extract lipid and then $0.5 \mathrm{ml}$ saturated potassium iodide solution was added and allowed to stand for $1 \mathrm{~min}$ with occasional shaking (swirling), $30 \mathrm{ml}$ of distilled water and $0.5 \mathrm{ml}$ of freshly prepared 0.5 percent starch solution were added. Flask contents were titrated immediately against $0.01 \mathrm{~N}$ sodium thiosulphate until intense blue colour disappeared. The peroxide value (meq/kg of the meat) was calculated as per the following formula.

$\mathrm{N}$ of sodium thiosulphate $\mathrm{x} \mathrm{ml} \mathrm{sodium} \mathrm{thiosulphate}$

used

$\begin{array}{lcc}\mathrm{PV} & (\mathrm{meq} / \mathrm{kg} \\ \text { sample }) & \text { = } & \text { X } 1000 \\ & \text { Wt. of sample }(\mathrm{g}) & \end{array}$


Microbiological analysis (Total Plate Count, Psychrotropic count, Coliform count and Yeast \& Mould Count): Samples was prepared and analyzed as per A.P.H.A., (1992).

\section{Sensory evaluation}

An experienced sensory panel consisting of seven scientists and post-graduate students of the university evaluated the sensory characteristics of the warmed product viz., appearance, flavour, juiciness, texture, saltiness, mouth coating and overall acceptability using 8-point objective scale where 8 denoted extremely desirable and 1 denoted extremely undesirable (Keeton, 1983).

\section{Statistical analysis}

The data obtained in the study on various parameters were statistically analyzed on 'SPSS-16.0' software package as per standard method. Data were subjected to one way analysis of variance, homogeneity test and Duncan's Multiple Range Test (DMRT) for comparing the means to find the effects between samples (Snedecor and Cochran, 1994).

\section{Results and Discussion}

\section{Physico- chemical parameters}

The mean $\mathrm{pH}$, TBA, FFA and peroxide values for control and functional chevon patties during storage at 3 days regular interval are presented in Table 3.

The recorded mean $\mathrm{pH}$ value for control chevon patties on day 0 and 15 were $6.26 \pm 0.02,6.30 \pm 0.02$ and $6.36 \pm 0.02$ whereas for functional chevon patties were $5.97 \pm 0.04$, and $6.06 \pm 0.02$ respectively. The $\mathrm{pH}$ values differed significantly $(\mathrm{P}<0.05)$ between treatments as well as during storage period.
The observed mean TBA (mg malonaldehyde $/ \mathrm{kg}$ ) value during storage on 0 and $15^{\text {th }}$ day for control chevon patties were $0.510 \pm 0.007$ and $0.983 \pm 0.039$ where as for functional chevon patties were $0.382 \pm 0.018$ and $0.677 \pm 0.019$ respectively. A significant $(\mathrm{P}<0.05)$ difference was observed between control and treatment throughout the storage period. The mean peroxide value was significantly $(\mathrm{P}<0.05)$ lower for functional chevon patties at each day of sampling throughout storage period Estimated FFA (\% oleic acid) values on day 0 and 15 in case of control and functional chevon patties were $0.370 \pm 0.012,0.737 \pm 0.015$ and $0.293 \pm 0.013$, $0.522 \pm 0.021$ respectively. The FFA value of functional chevon patties were significantly $(\mathrm{P}<0.05)$ lower than control throughout the study period. A significant $(\mathrm{P}<0.05)$ increase in FFA value of control and functional chevon was also observed with the advancement of storage.

The observed mean peroxide (meq/kg) values during storage on day 0 and 15 for control chevon patties were $1.82 \pm 0.04$ and $9.20 \pm 0.09$ whereas for functional chevon patties were $1.22 \pm 0.04$ and $6.05 \pm 0.16$ respectively. The mean peroxide value differed significantly $(\mathrm{P}<0.05)$ between treatment as well as storage days. The mean peroxide value was significantly $(\mathrm{P}<0.05)$ lower in functional chevon patties during the period under study was conducted.

\section{Microbiological analysis}

The mean total plate counts, lipolytic counts, psychrotrophic counts, coliform counts and counts for yeast and molds $\left(\log _{10} \mathrm{cfu} / \mathrm{g}\right)$ for control and functional chevon patties during storage study are presented in Table 4 .

The observed mean TPC value for control chevon patties on day 0 and 15 were 2.58 \pm 0.08 and $4.78 \pm 0.14$, whereas for functional chevon patties were $2.21 \pm 0.07$ and $3.85 \pm 0.07$ 
respectively. The mean TPC values increased significantly $(\mathrm{P}<0.05)$ for control and treatment during the storage period. Significant $(\mathrm{P}<0.05)$ difference was observed between control and treatment throughout the storage.

The observed mean lipolytic counts in control chevon patties on day 0 were $1.47 \pm 0.04$ which increased significantly $(\mathrm{P}<0.05)$ to $3.05 \pm 0.09$ on day 15 . The recorded mean lipolytic counts in functional chevon patties was found significantly $(\mathrm{P}<0.05)$ lower than control group. The mean counts in functional chevon patties ranged between $1.18 \pm 0.06$ at Day 0 to $2.06 \pm 0.07$ at Day 15 .

The psychrotrophic counts were absent till day 12 in both control and functional chevon patties. The mean psychrotrophic count for control and function chevon patties at day 15 were observed to be $2.12 \pm 0.06$ and $2.03 \pm 0.07$ respectively. The counts increased significantly $(\mathrm{P}<0.05)$ after day 12 in both the groups. No significant $(\mathrm{P}>0.05)$ difference was observed between control and treatment during entire storage.

None of coliform count was detected during the storage period. The yeast and mold counts for control as well as for functional chevon patties were not observed up to $12^{\text {th }}$ day of storage. However, mean counts on day 15 were recorded as $1.80 \pm 0.05$ and $1.34 \pm 0.04$ in control and functional chevon patties respectively. The counts differed significantly $(\mathrm{P}<0.05)$ between the treatments.

\section{Sensory evaluation}

The mean scores of general appearance, flavor, texture, saltiness, juiciness, mouth coating and overall acceptability for control and functional chevon patties during storage study are presented in Table 5.
The recorded mean scores of general appearance for control and functional chevon patties on day 0 were $6.96 \pm 0.05$ and 6.94 \pm 0.07 respectively. The scores decreased significantly $(\mathrm{P}<0.05) \quad$ during storage, however, no significant $(\mathrm{P}>0.05)$ difference was observed between control and treatment throughout the undertaken study.

The recorded mean scores of flavor of control and functional chevon patties on day 0 were $7.14 \pm 0.08$ and $7.13 \pm 0.08$ respectively, which were decreased significantly $(\mathrm{P}<0.05)$ to $5.64 \pm 0.10$ and $6.00 \pm 0.06$ on day 15 with advancement of storage. However, during storage from day $12^{\text {th }}$ onward significant $(\mathrm{P}<0.05)$ difference between treatments was recorded.

The recorded texture scores during storage on day 0 and 15 for control chevon patties were $7.07 \pm 0.07$ and $5.50 \pm 0.11$ whereas for functional chevon patties were $7.04 \pm 0.07$ and $5.95 \pm 0.09$ respectively. The mean texture scores decreased significantly $(\mathrm{P}<0.05)$ with storage time. However, a higher texture score for functional chevon patties was recorded throughout the study and significant $(\mathrm{P}<0.05)$ difference was observed between control and treatment on $12^{\text {th }}$ and $15^{\text {th }}$ day of storage.

The mean saltiness scores in control chevon patties were marginally decreased from $7.00 \pm 0.07$ at day 0 to $6.81 \pm 0.06$ at day 15 . However, saltiness scores of functional chevon patties decreased gradually and became significant $(\mathrm{P}<0.05)$ on $15^{\text {th }}$ day of storage. A significant $(\mathrm{P}<0.05)$ difference was observed between treatments on $12^{\text {th }}$ and $15^{\text {th }}$ day of storage.

The observed mean scores of juiciness for control and functional chevon patties on day 0 were $6.88 \pm 0.06$ and $7.16 \pm 0.07$ respectively which, decreased significantly $(\mathrm{P}<0.05)$ and reached to $5.70 \pm 0.09$ and $5.98 \pm 0.06$ 
respectively on $15^{\text {th }}$ day of storage. Significant $(\mathrm{P}<0.05)$ difference was observed between control and functional chevon patties on each day of sampling during the study.

The recorded mean scores of mouth coating for control and functional chevon patties on day 0 were $6.72 \pm 0.07$ and $6.96 \pm 0.06$ respectively. The scores decreased significantly $(\mathrm{P}<0.05)$ and reached to 5.75 \pm 0.09 and $5.98 \pm 0.06$ respectively on day 15 during storage. However, no significant $(\mathrm{P}>0.05)$ difference was observed between control and treatment throughout the undertaken study.

The recorded mean scores of overall acceptability of control and functional chevon patties on day 0 were $7.09 \pm 0.07$ and 7.11 \pm 0.07 respectively, which decreased significantly $(\mathrm{P}<0.05)$ to $5.79 \pm 0.06$ and $6.11 \pm 0.06$ on day 15 with advancement of storage. However, during storage on day 15 significant $\quad(\mathrm{P}<0.05)$ difference between treatments was recorded.

\section{Physico-chemical properties}

The mean $\mathrm{pH}$, TBA, FFA and PV values with their standard error of control and functional (antioxidant added low fat-low sodium) chevon patties during storage (Day 0, 3, 6,9,12 and 15) are presented in Table 3.

The $\mathrm{pH}$ of functional chevon patties at 0 day was significantly $(\mathrm{P}<0.0 .5) \quad$ lower as compared to control and remained so throughout the storage. Lower $\mathrm{pH}$ in functional patties was probably by additive effect of salt substitute blend and acidic $\mathrm{pH}$ of noni juice. The $\mathrm{pH}$ value of control as well as functional chevon patties increased gradually and significantly $(\mathrm{P}<0.05)$ from $6^{\text {th }}$ to $9^{\text {th }}$ day of storage. However, then $\mathrm{pH}$ value was decreased slightly on further storage. Such decline in $\mathrm{pH}$ might be due to the action of psychrotrophic bacteria which ferment the carbohydrate present in the ingredients used in the formulation of the product and the subsequent increment of $\mathrm{pH}$ was due to the liberation of metabolites from the bacterial activity as the microbial load enhanced with storage period. However, significant $(\mathrm{P}<0.05)$ increment in $\mathrm{pH}$ values up to $9^{\text {th }}$ day might be attributed to excess of initial microbial activity which produces amine from protein break down, over the action of psychrotrophic bacterial carbohydrate fermentation. Das et al., (2014) reported similar trend in $\mathrm{pH}$ of meat cake during storage. Nayak and Tanwar (2004) also noticed increasing in $\mathrm{pH}$ during refrigerated storage of different meat products.

During lipid oxidation, malonaldehyde (MA), a minor component of fatty acids with 3 or more double bonds, is formed as a result of the degradation of polyunsaturated fatty acids can be estimated by the reaction with TBA and the TBA value is routinely used as an index of lipid oxidation in meat products (Raharjo and Sofos, 1993). The TBA value for control product was significantly $(\mathrm{P}<0.0 .5)$ higher as compared to functional chevon patties throughout the entire storage. Higher TBA value for control might be due to higher salt content (a pro-oxidant) and absence of antioxidants in this product. Rate of oxidation in functional chevon patties was very slow resulting significantly $(\mathrm{P}<0.05)$ lower TBA value compared to control. This might be due to large amount of phytochemicals contained in noni which acts as reductones by donating electrons and reacting with free radicals to convert them to more stable products and terminate free radical chain reactions. Increase in TBA could be due to increased lipid oxidation and production of volatile metabolites in the presence of oxygen during storage period. But lower TBARS in functional patties indicate that the noni treatment was inhibiting 
oxidation, thus improving stability. These findings are in accordance with the Tapp et al., (2010) who reported that after 5 days, patties with $0 \%$ Noni had significantly $(\mathrm{P}<$ 0.05) higher TBARS compared to $6 \%$ Noni and noni pulp. Nayak et al., (2014) also observed lower TBA value in tofu incorporate chicken meat nuggets and increased TBA value with increasing storage period.

FFA value is a measure of hydrolytic rancidity in foods. Free fatty acids are the products of enzymatic or microbial degradation of lipids and determination of FFA gives information about stability of fat during storage (Das et al., 2008). The FFA value for functional chevon patties remained significantly $(\mathrm{P}<0.0 .5)$ lower as compared to control throughout the entire storage. This could be due to presence of phytochemicals, including deacetylasperulosidic acid (DAA) and asperulosidic acid (AA), which are iridoids, as well as scopoletin, rutin, and quercetin in noni (West et al., 2011). These compounds have phenolic, ring-type chemical structures, which are similar to those found in other natural antioxidants. The overall mean for free fatty acid values (percent oleic acid) of control chevon patties showed a significant $(\mathrm{P}<0.0 .5)$ increasing trend from $6^{\text {th }}$ to $15^{\text {th }}$ day of storage. This might be due to progressive oxidation of lipids during storage. However, FFA value for functional chevon patties was remained unaffected up to $9^{\text {th }}$ day of storage and then increased significantly $(\mathrm{P}<0.0 .5)$ during storage. Sahoo and Anjaneyulu (1997) reported that the FFA in sodium ascorbates, $\alpha$ tocopherol acetate and sodium tripolyphosphate treated aerobic packaged buffalo meat nuggets was increased due to growth of some lypolytic microorganisms.

The peroxide value (PV) represents the total hydroperoxide content and is one of the most common quality indicators of fats and oils during production and storage (Ruiz et al.,
2001). Both control and functional chevon patties showed a gradual significant $(\mathrm{P}<0.05)$ change in peroxide value with advancement of storage period. Numerically, all the values were far below of $20 \mathrm{meq} / \mathrm{kg}$. However, peroxide value remains significantly $(\mathrm{P}<0.05)$ lower for functional products at all storage days. The comparatively slow oxidation of fat in functional chevon patties could be due to antioxidant effect of noni. The data was supported by the findings of Das et al., (2014) who reported significant effect $(\mathrm{P}<0.01)$ of storage period on the $\mathrm{PV}$ of meat samples.

Lower pH, TBA, FFA and Peroxide value during storage might be due to synergistic effect of noni and carrageenan in functional chevon patties compared to control. These findings were in accordance with Mokhtar et al., (2014) who concluded that the combination of rosemary extract with chitosan provided the best antioxidative protection with regard to meat deterioration, indicating a possible synergistic effect.

\section{Microbiological quality}

The mean total plate count, lipolytic count psychrotrophic count, coliform count and yeast and mold count with their standard error of control and functional (antioxidant added low fat-low sodium) chevon patties during storage (Day 0, 3, 6,9,12 and 15) are presented in Table 4.

The total plate count (TPC) followed a gradual increasing pattern from 0 to $15^{\text {th }}$ day in control and functional chevon patties, but these were well within the permissible limits for cooked meat products prescribed by Jay (1996). However, the growth of microbes was comparatively slow in functional chevon patties. The significantly $(\mathrm{P}<0.05)$ lower count of TPC in functional chevon patties was observed as compared to control throughout 
the storage which could be attributed to the lower $\mathrm{pH}$ resulting inhibition of microbial growth of spoilage organism. Noni also have been reported to possess great antimicrobial activity which might have inhibited the growth of microbes (Sunder et al., 2011). The anti microbial property of noni is due to presence of phytoconstituents viz., phenol, alkaloid, flavonoids, glycosides tannins, saponin and steroids at various levels (Sibi et al., 2012). Increasing trend with the advancement of storage was also reported by other workers Bhat et al., (2013 a\&b) and Nayak et al., (2014) in chicken meat balls and chicken nuggets respectively.

There were significantly $(\mathrm{P}<0.05)$ lower lipolytic counts in functional chevon patties as compared to control throughout the storage which could be attributed to the lower fat content in the functional chevon patties. The lipolytic count increased significantly $(\mathrm{P}<0.05)$ with the advancement of storage. The lower growth rate of lipolytic count in functional chevon patties may be due to anti microbial property of noni (Sibi et al., 2012). Nayak and Tanwar (2004) also reported increasing lipolytic count in tofu incorporated chicken patties with advancement of storage.

Psychrotrophs were not detected up to day 9 of storage either in control or functional chevon patties. This could be due to destruction of psychrotrophs during cooking. These counts were detected on $12^{\text {th }}$ day of storage and thereafter increased significantly $(\mathrm{P}<0.05)$ at each storage interval in both control and functional chevon patties. This might be due to recovery of injured organisms and then multiplication during subsequent period of storage. Psychrotrophic count between control and functional chevon patties did not differ significantly $(\mathrm{P}>0.05)$ and count remained within the permissible limit of log $4.6 \mathrm{cfu} / \mathrm{g}$ as reported by Cremer and Chipley (1997) in cooked meat products.
Coliform were not detected during the entire period of storage in both in control or functional chevon patties. The absence of coliform could be due to their destruction during cooking at $180^{\circ} \mathrm{C}$ much above their death point of $57{ }^{\circ} \mathrm{C}$. Further hygienic practices followed during and after preparation of products. Similar results of zero count of coliforms in the products heated to such a high temperature were reported by Kandeepan et al., (2010) in buffalo meat keema, Bhat et al., (2013a) in chicken Seekh Kababs and Bhat et al., (2013b) in chicken meat balls.

Yeast and mould count was detected only on $15^{\text {th }}$ day of storage. However, value for yeast and mould was significantly $(\mathrm{P}<0.05)$ lower in functional chevon patties as compared to control. This might be due to absence of favorable condition (like humid climate) for the growth of yeast and mould during experiment. Das et al., (2013) and Raja et al., (2014) also reported similar results in chicken nuggets.

\section{Sensory attributes}

The mean score of general appearance, flavor, texture, saltiness, juiciness, mouth coating and overall acceptability with their standard error for control and functional chevon patties during storage (day 0, 3, 6, 9, 12 and 15) are presented in Table 5.

Appearance is a sensory attribute and refers to the physical outlook of the meat product. The scores for general appearance did not have any significant $(\mathrm{P}>0.05)$ difference between control and functional chevon patties on all storage days. The higher scores for functional chevon patties as compared to control was noticed in last phase of storage. This might be due to antioxidant properties of noni which slowed down the lipid oxidation and ultimately resisted change in appearance in 
terms of color. Mean scores for general appearance of both control and functional chevon patties decreased gradually with increase in storage period. However, score significantly $(\mathrm{P}<0.05)$ decreased on $6^{\text {th }}$ day and then from $12^{\text {th }}$ day of storage period. The decreased in general appearance scores with the progression of storage period might be due to some pigment and lipid oxidation resulting in non enzymatic browning as well as surface dehydration in aerobic packaging. Similar results were reported by Kala et al., (2007) in refrigerated chicken patties.

Flavor is a complex sensation comprising mainly of odor and taste of product and sensed collectively by oral and olfactory senses. Mean flavor scores between control and functional chevon patties did not differ significantly $(\mathrm{P}>0.05)$ up to $9^{\text {th }}$ day of storage. However, on subsequent storage significantly $(\mathrm{P}<0.05)$ higher score for functional chevon patties was recorded. Natural antioxidants in functional chevon patties might be responsible to prevent breakdown of lipid product and other nutrients. There was gradual decrease in flavor score of control as well as functional chevon patties. The less decrease for flavor scores in functional chevon patties might be due to lower lipid oxidation as well as presence of various aromatic and flavinoids compounds present in noni. These data are in agreement with Mohamed and Mansour (2012) who reported that the flavor scores of beef patties prepared without addition of antioxidants were significantly $(\mathrm{P}<0.05)$ lower than those of other formulas..

Functional chevon patties showed significantly $(\mathrm{P}<0.05)$ higher texture score as compared to control from $12^{\text {th }}$ day of storage period. Lower texture in control patties might be due to rapid increase in $\mathrm{pH}$ and bacterial load with the advancement of storage period. There was gradual decrease in texture score of control as well as functional chevon patties. Texture scores for control were decreased from day 9 of storage. However, texture of functional chevon patties was unaffected up to day 9 of storage but on subsequent advancement of storage period significant $(\mathrm{P}<0.05)$ difference was observed. Gradual decrease in texture might be due to break down of meat protein. The decreasing trend in texture scores during storage under refrigeration in chicken were also reported by Nayak et al., (2014) in meat nuggets and Nayak et al., (2006) in tofu incorporated chicken meat patties.

The scores for saltiness did not have any significant $\quad(\mathrm{P}>0.05)$ difference between control and functional chevon patties on all storage days. With advancement in storage period no significant $(\mathrm{P}>0.05)$ differences was recorded in saltiness score of control chevon patties throughout the storage period. However, saltiness score for functional chevon patties decreased significantly $(\mathrm{P}<0.05)$ on $15^{\text {th }}$ day of storage. This could be due to addition of salt substitute blend in the functional chevon patties.

The significantly $(\mathrm{P}<0.05)$ higher score of juiciness for functional chevon patties as compared to control was observed throughout the storage. This might be due to higher water and fat retention capacity of carrageenan in the functional chevon patties. A gradual decrease in juiciness score for control as well as functional chevon patties was recorded with the advancement of storage. Juiciness score for control and functional chevon patties were not affected significantly $(\mathrm{P}>0.05)$ up to $9^{\text {th }}$ and $12^{\text {th }}$ day of storage respectively. However, the scores decreased on further storage. Decrease in juiciness score could be attributed to some moisture loss from the products during aerobic storage. Chandralekha et al., (2012) also observed higher juiciness in antioxidant incorporated 
meat ball and further they also reported decreasing score with increasing storage. Ibrahim (2012) reported decreasing score in beef patties.

There was no significant $(\mathrm{P}>0.05)$ difference in mouth coating scores between control and functional chevon patties on all storage days. However, sensory panelist rated higher mouth coating score for functional chevon patties throughout the storage. With increasing storage period mean mouth coating scores decreased significantly $(\mathrm{P}<0.05)$ from $12^{\text {th }}$ day of storage and followed similar pattern by control as well as functional product.

The decrease in mouth coating scores might be due to lipid and protein oxidation during storage. Uikey et al., (2018) also reported similar observation in kadaknath chicken nuggets.

Table.1 Composition of spice mix

\begin{tabular}{|c|c|c|}
\hline S. No. & Name of ingredients & Percentage of $\mathbf{~ m i x . ~ ( w / w ) ~}$ \\
\hline $\mathbf{1 .}$ & Anise & 10 \\
\hline $\mathbf{2 .}$ & Black pepper & 5 \\
\hline $\mathbf{3 .}$ & Capsicum & 10 \\
\hline $\mathbf{4 .}$ & Caraway & 10 \\
\hline $\mathbf{5 .}$ & Cardamom & 4 \\
\hline $\mathbf{6 .}$ & Cloves & 2 \\
\hline $\mathbf{7 .}$ & Cinnamon & 4 \\
\hline $\mathbf{8 .}$ & Cumin & 20 \\
\hline $\mathbf{9 .}$ & Dry ginger & 10 \\
\hline $\mathbf{1 0 .}$ & Turmeric & 10 \\
\hline $\mathbf{1 1}$ & Coriander & 15 \\
\hline
\end{tabular}

Table.2 Formulation for control and functional (antioxidant added low fat-low sodium) chevon patties

\begin{tabular}{|l|l|l|l|}
\hline S.N. & Ingredient & Control & Functional \\
\hline $\mathbf{1}$ & Lean goat meat & 70 & 70 \\
\hline $\mathbf{2}$ & Refined vegetable oil & 10 & 5 \\
\hline & Carrageenan & 0 & 0.6 \\
\hline $\mathbf{3}$ & Ice flakes & 10 & 11.4 \\
\hline $\mathbf{4}$ & Nacl & 1.6 & 1.0 \\
\hline & KCl & 0 & 0.4 \\
\hline & Cacl $_{2}$ & 0 & 0.2 \\
\hline $\mathbf{5}$ & Dry spices mix & 2.0 & 2.0 \\
\hline $\mathbf{6}$ & Condiments & 3.0 & 3.0 \\
\hline $\mathbf{7}$ & Refined wheat flour & 3.0 & 3.0 \\
\hline $\mathbf{8}$ & STTP & 0.4 & 0.4 \\
\hline $\mathbf{9 .}$ & Noni Juice & 0.0 & 3.0 \\
\hline & Total & $\mathbf{1 0 0}$ & $\mathbf{1 0 0}$ \\
\hline
\end{tabular}


Table.3 Effect of refrigerated storage $\left(4 \pm 1^{\circ} \mathrm{C}\right)$ on the $\mathrm{pH}$, TBA value, FFA value and peroxide value of aerobically packaged control and functional chevon patties

\begin{tabular}{|c|c|c|c|c|c|c|}
\hline \multirow[t]{2}{*}{ Treatments } & \multicolumn{6}{|c|}{ Storage days } \\
\hline & $\mathbf{0}$ & 3 & 6 & 9 & 12 & 15 \\
\hline \multicolumn{7}{|c|}{$\mathbf{p H}$} \\
\hline Control & $\begin{array}{l}6.26^{\mathrm{Ba}} \\
\pm 0.02\end{array}$ & $\begin{array}{l}6.30^{\mathrm{Ba}} \\
\pm 0.02\end{array}$ & $\begin{array}{c}6.38^{\mathrm{Bb}} \\
\pm 0.01\end{array}$ & $\begin{array}{l}6.44^{\mathrm{Bc}} \\
\pm 0.02\end{array}$ & $\begin{array}{c}6.40^{\mathrm{Bbc}} \\
\pm 0.02\end{array}$ & $\begin{array}{l}6.36^{\mathrm{Bb}} \\
\pm 0.02\end{array}$ \\
\hline Treatment & $\begin{array}{l}5.97^{\mathrm{Aa}} \\
\pm 0.04\end{array}$ & $\begin{array}{l}6.02^{\mathrm{Aa}} \\
\pm 0.02\end{array}$ & $\begin{array}{c}6.06^{\text {Aab }} \\
\pm 0.02\end{array}$ & $\begin{array}{l}6.14^{\mathrm{Ab}} \\
\pm 0.02\end{array}$ & $\begin{array}{l}6.10^{\mathrm{Ab}} \\
\pm 0.02\end{array}$ & $\begin{array}{c}6.06^{\mathrm{Aab}} \\
\pm 0.02\end{array}$ \\
\hline \multicolumn{7}{|c|}{ TBA (mg malonaldehyde/kg)) } \\
\hline Control & $\begin{array}{l}0.510^{\mathrm{Ba}} \\
\pm 0.007\end{array}$ & $\begin{array}{c}0.566^{\mathrm{Ba}} \\
\pm 0.023\end{array}$ & $\begin{array}{c}0.650^{\mathrm{Bb}} \\
\pm 0.028\end{array}$ & $\begin{array}{l}0.737^{\mathrm{Bc}} \\
\pm 0.020\end{array}$ & $\begin{array}{c}0.853^{\mathrm{Bd}} \\
\pm 0.027\end{array}$ & $\begin{array}{c}0.983^{\mathrm{Be}} \\
\pm 0.039\end{array}$ \\
\hline Treatment & $\begin{array}{c}0.382^{\mathrm{Aa}} \\
\pm 0.018\end{array}$ & $\begin{array}{c}0.427^{\mathrm{Aa}} \\
\pm 0.021\end{array}$ & $\begin{array}{c}0.485^{\text {Aab }} \\
\pm 0.023\end{array}$ & $\begin{array}{c}0.555^{\mathrm{Ab}} \\
\pm 0.027\end{array}$ & $\begin{array}{c}0.612^{\mathrm{Abc}} \\
\pm 0.027\end{array}$ & $\begin{array}{c}0.677^{\mathrm{Ac}} \\
\pm 0.019\end{array}$ \\
\hline \multicolumn{7}{|c|}{ FFA (\% oleic acid $)$} \\
\hline Control & $\begin{array}{c}0.370^{\mathrm{Ba}} \\
\pm 0.012\end{array}$ & $\begin{array}{c}0.407^{\mathrm{Ba}} \\
\pm 0.019\end{array}$ & $\begin{array}{c}0.477^{\mathrm{Bb}} \\
\pm 0.023\end{array}$ & $\begin{array}{l}0.558^{\mathrm{Bc}} \\
\pm 0.024\end{array}$ & $0.677^{\mathrm{Bd}} \pm 0.019$ & $\begin{array}{l}0.737^{\mathrm{Be}} \\
\pm 0.015\end{array}$ \\
\hline Treatment & $\begin{array}{c}0.293^{\mathrm{Aa}} \\
\pm 0.013\end{array}$ & $\begin{array}{c}0.328^{\text {Aab }} \\
\pm 0.017\end{array}$ & $\begin{array}{c}0.358^{\mathrm{Aab}} \\
\pm 0.018\end{array}$ & $\begin{array}{c}0.375^{\mathrm{Ab}} \\
\pm 0.023\end{array}$ & $0.488^{\mathrm{Ac}} \pm 0.021$ & $\begin{array}{c}0.522^{\text {Acd }} \\
\pm 0.021\end{array}$ \\
\hline \multicolumn{7}{|c|}{ Peroxide value (meq/kg) } \\
\hline Control & $\begin{array}{l}1.82^{\mathrm{Ba}} \\
\pm 0.04\end{array}$ & $\begin{array}{c}3.20^{\mathrm{Bb}} \\
\pm 0.09\end{array}$ & $\begin{array}{c}4.41^{\mathrm{Bc}} \\
\pm 0.07\end{array}$ & $\begin{array}{c}6.10^{\mathrm{Bd}} \\
\pm 0.08\end{array}$ & $\begin{array}{l}7.60^{\mathrm{Be}} \\
\pm 0.07\end{array}$ & $\begin{array}{l}9.20^{\mathrm{Bf}} \\
\pm 0.09\end{array}$ \\
\hline Treatment & $\begin{array}{l}1.22^{\mathrm{Aa}} \\
\pm 0.04\end{array}$ & $\begin{array}{l}1.80^{\mathrm{Ab}} \\
\pm 0.08\end{array}$ & $\begin{array}{l}2.40^{\mathrm{Ac}} \\
\pm 0.07\end{array}$ & $\begin{array}{l}3.12^{\mathrm{Ad}} \\
\pm 0.06\end{array}$ & $\begin{array}{l}4.50^{\mathrm{Ae}} \\
\pm 0.07\end{array}$ & $\begin{array}{l}6.05^{\text {Af }} \\
\pm 0.16\end{array}$ \\
\hline
\end{tabular}

Means bearing different superscripts rows wise $(\mathrm{a}, \mathrm{b}, \mathrm{c}, \mathrm{d} \ldots .$.$) and columns wise (A, B ) differ significantly (\mathrm{P}<0.05)$

Table.4 Effect of refrigerated storage $\left(4 \pm 1^{\circ} \mathrm{C}\right)$ on the microbiological quality of aerobically packaged control and functional chevon patties

\begin{tabular}{|c|c|c|c|c|c|c|}
\hline \multirow[t]{2}{*}{ Treatments } & \multicolumn{6}{|c|}{ Storage days } \\
\hline & $\mathbf{0}$ & 3 & 6 & 9 & 12 & 15 \\
\hline \multicolumn{7}{|c|}{ Total plate count $\left(\log _{10} \mathrm{cfu} / \mathrm{g}\right)$} \\
\hline Control & $\begin{array}{l}2.58^{\mathrm{Ba}} \\
\pm 0.08\end{array}$ & $\begin{array}{l}2.96^{\mathrm{Ba}} \\
\pm 0.10\end{array}$ & $\begin{array}{l}3.48^{\mathrm{Bb}} \\
\pm 0.10\end{array}$ & $\begin{array}{l}3.95^{\mathrm{Bc}} \\
\pm 0.09\end{array}$ & $\begin{array}{c}4.28^{\mathrm{Bd}} \\
\pm 0.08\end{array}$ & $\begin{array}{l}4.78^{\mathrm{Be}} \\
\pm 0.14\end{array}$ \\
\hline Treatment & $\begin{array}{l}2.21^{\mathrm{Aa}} \\
\pm 0.07\end{array}$ & $\begin{array}{c}2.32^{\mathrm{Aa}} \\
\pm 0.09\end{array}$ & $\begin{array}{c}2.54^{\text {Aab }} \\
\pm 0.11\end{array}$ & $\begin{array}{c}2.88^{\mathrm{Ab}} \\
\pm 0.07\end{array}$ & $\begin{array}{l}3.25^{\mathrm{Ac}} \\
\pm 0.09\end{array}$ & $\begin{array}{c}3.85^{\mathrm{Ad}} \\
\pm 0.07\end{array}$ \\
\hline \multicolumn{7}{|c|}{ Lipolytic count $\left(\log _{10} \mathrm{cfu} / \mathrm{g}\right)$} \\
\hline Control & $\begin{array}{l}1.47^{\mathrm{Ba}} \\
\pm 0.04\end{array}$ & $\begin{array}{l}1.62^{\mathrm{Ba}} \\
\pm 0.07\end{array}$ & $\begin{array}{c}1.88^{\mathrm{Bbc}} \\
\pm 0.08\end{array}$ & $\begin{array}{c}2.12^{\mathrm{Bcd}} \\
\pm 0.05\end{array}$ & $\begin{array}{l}2.37^{\mathrm{Bd}} \\
\pm 0.09\end{array}$ & $\begin{array}{l}3.05^{\mathrm{Be}} \\
\pm 0.09\end{array}$ \\
\hline Treatment & $\begin{array}{l}1.18^{\mathrm{Aa}} \\
\pm 0.06\end{array}$ & $\begin{array}{l}1.25^{\mathrm{Aa}} \\
\pm 0.06\end{array}$ & $\begin{array}{l}1.33^{\mathrm{Aab}} \\
\pm 0.04\end{array}$ & $\begin{array}{l}1.41^{\mathrm{Ab}} \\
\pm 0.07\end{array}$ & $\begin{array}{l}1.80^{\mathrm{Ac}} \\
\pm 0.05\end{array}$ & $\begin{array}{l}2.06^{\text {Ad }} \\
\pm 0.07\end{array}$ \\
\hline \multicolumn{7}{|c|}{ Psychrotrophic count $\left(\log _{10} \mathrm{cfu} / \mathrm{g}\right)$} \\
\hline Control & ND & ND & ND & ND & $\begin{array}{l}1.35^{\mathrm{a}} \\
\pm 0.08\end{array}$ & $\begin{array}{l}2.12^{\mathrm{b}} \\
\pm 0.06\end{array}$ \\
\hline Treatment & ND & ND & ND & ND & $\begin{array}{r}1.28^{\mathrm{a}} \\
\pm 0.06\end{array}$ & $\begin{array}{l}2.03^{b} \\
\pm 0.07\end{array}$ \\
\hline \multicolumn{7}{|c|}{ Coliform count ( $\log _{10} \mathrm{cfu} / \mathrm{g}$ ) } \\
\hline Control & ND & ND & ND & ND & ND & ND \\
\hline Treatment & ND & ND & ND & ND & ND & ND \\
\hline \multicolumn{7}{|c|}{ Yeast and mold ( $\left.\log _{10} \mathrm{cfu} / \mathrm{g}\right)$} \\
\hline Control & ND & ND & ND & ND & ND & $\begin{array}{l}1.80^{\mathrm{B}} \\
\pm 0.05\end{array}$ \\
\hline Treatment & ND & ND & ND & ND & ND & $\begin{array}{l}1.34^{\mathrm{A}} \\
\pm 0.04\end{array}$ \\
\hline
\end{tabular}

Means bearing different superscripts rows wise $(\mathrm{a}, \mathrm{b}, \mathrm{c}, \mathrm{d} \ldots .$.$) and columns wise (\mathrm{A}, \mathrm{B})$ differ significantly $(\mathrm{P}<0.05)$ 
Table.5 Effect of refrigerated storage $\left(4 \pm 1^{\circ} \mathrm{C}\right)$ on sensory attributes of aerobically packaged control and functional chevon patties

\begin{tabular}{|c|c|c|c|c|c|c|}
\hline \multirow[t]{2}{*}{ Treatments } & \multicolumn{6}{|c|}{ Storage days } \\
\hline & $\mathbf{0}$ & 3 & 6 & 9 & 12 & 15 \\
\hline \multicolumn{7}{|c|}{ General appearance } \\
\hline Control & $\begin{array}{l}6.96^{d} \\
\pm 0.05^{2}\end{array}$ & $\begin{array}{l}6.89^{\mathrm{cd}} \\
\pm 0.06\end{array}$ & $\begin{array}{l}6.72^{\mathrm{c}} \\
\pm 0.06\end{array}$ & $\begin{array}{l}6.58^{b c} \\
\pm 0.08\end{array}$ & $\begin{array}{l}6.40^{b} \\
\pm 0.06\end{array}$ & $\begin{array}{l}6.08^{\mathrm{a}} \\
\pm 0.07\end{array}$ \\
\hline Treatment & $\begin{array}{l}6.94^{d} \\
\pm 0.07\end{array}$ & $\begin{array}{l}6.89^{\mathrm{cd}} \\
\pm 0.06\end{array}$ & $\begin{array}{l}6.79^{c} \\
\pm 0.07\end{array}$ & $\begin{array}{l}6.61^{b c} \\
\pm 0.08\end{array}$ & $\begin{array}{l}6.50^{b} \\
\pm 0.07\end{array}$ & $\begin{array}{l}6.29^{a} \\
\pm 0.06\end{array}$ \\
\hline \multicolumn{7}{|c|}{ Flavor } \\
\hline Control & $\begin{array}{l}7.14^{\mathrm{Ae}} \\
\pm 0.08\end{array}$ & $\begin{array}{c}7.08^{\text {A de }} \\
\pm 0.07\end{array}$ & $\begin{array}{c}6.83^{\mathrm{Ad}} \\
\pm 0.07\end{array}$ & $\begin{array}{l}6.50^{\mathrm{Ac}} \\
\pm 0.07\end{array}$ & $\begin{array}{l}6.18^{\mathrm{Ab}} \\
\pm 0.06\end{array}$ & $\begin{array}{c}5.64^{\mathrm{Aa}} \\
\pm 0.10\end{array}$ \\
\hline Treatment & $\begin{array}{l}7.13^{\mathrm{Ad}} \\
\pm 0.08\end{array}$ & $\begin{array}{l}7.06^{\mathrm{Ad}} \\
\pm 0.07\end{array}$ & $\begin{array}{c}6.98 \text { Adc } \\
\pm 0.05\end{array}$ & $\begin{array}{c}6.74^{\mathrm{Abc}} \\
\pm 0.07\end{array}$ & $\begin{array}{c}6.45^{\mathrm{Bb}} \\
\pm 0.07\end{array}$ & $\begin{array}{l}6.00^{\mathrm{Ba}} \\
\pm 0.06\end{array}$ \\
\hline \multicolumn{7}{|c|}{ Texture } \\
\hline Control & $\begin{array}{c}7.07^{\mathrm{Ad}} \\
\pm 0.07\end{array}$ & $\begin{array}{c}6.95^{\text {Acd }} \\
\pm 0.05\end{array}$ & $\begin{array}{c}6.70^{\mathrm{Ac}} \\
\pm 0.07\end{array}$ & $\begin{array}{c}6.39^{\mathrm{Ac}} \\
\pm 0.06\end{array}$ & $\begin{array}{c}6.00^{\mathrm{Ab}} \\
\pm 0.06\end{array}$ & $\begin{array}{c}5.50^{\mathrm{Aa}} \\
\pm 0.11\end{array}$ \\
\hline Treatment & $\begin{array}{l}7.04^{\mathrm{Ac}} \\
\pm 0.07\end{array}$ & $\begin{array}{c}6.95^{\mathrm{Ac}} \\
\pm 0.05\end{array}$ & $\begin{array}{c}6.71^{\mathrm{Abc}} \\
\pm 0.06\end{array}$ & $\begin{array}{c}6.52^{\mathrm{Ab}} \\
\pm 0.07\end{array}$ & $\begin{array}{c}6.25^{\mathrm{Bab}} \\
\pm 0.05\end{array}$ & $\begin{array}{c}5.95^{\mathrm{Ba}} \\
\pm 0.09\end{array}$ \\
\hline \multicolumn{7}{|c|}{ Saltiness } \\
\hline Control & $\begin{array}{c}7.00 \\
\pm 0.07\end{array}$ & $\begin{array}{c}6.96 \\
\pm 0.06\end{array}$ & $\begin{array}{c}6.93 \\
\pm 0.07\end{array}$ & $\begin{array}{c}6.90 \\
\pm 0.07\end{array}$ & $\begin{array}{c}6.85 \\
\pm 0.06\end{array}$ & $\begin{array}{c}6.81 \\
\pm 0.06\end{array}$ \\
\hline Treatment & $\begin{array}{l}7.08^{b} \\
\pm 0.07\end{array}$ & $\begin{array}{l}7.04^{\mathrm{ab}} \\
\pm 0.07\end{array}$ & $\begin{array}{l}7.00^{\mathrm{ab}} \\
\pm 0.07\end{array}$ & $\begin{array}{l}6.94^{\mathrm{ab}} \\
\pm 0.08\end{array}$ & $\begin{array}{l}6.88^{a b} \\
\pm 0.07\end{array}$ & $\begin{array}{l}6.79^{\mathrm{a}} \\
\pm 0.06\end{array}$ \\
\hline \multicolumn{7}{|c|}{ Juiciness } \\
\hline Control & $\begin{array}{c}6.88^{\mathrm{Ad}} \\
\pm 0.06\end{array}$ & $\begin{array}{c}6.80^{\mathrm{Ad}} \\
\pm 0.05\end{array}$ & $\begin{array}{c}6.70^{\mathrm{Ad}} \\
\pm 0.07\end{array}$ & $\begin{array}{l}6.36^{\mathrm{Ac}} \\
\pm 0.06\end{array}$ & $\begin{array}{c}5.99^{\mathrm{Ab}} \\
\pm 0.06\end{array}$ & $\begin{array}{l}5.70^{\mathrm{Aa}} \\
\pm 0.09\end{array}$ \\
\hline Treatment & $\begin{array}{l}7.16^{\mathrm{Bd}} \\
\pm 0.07\end{array}$ & $\begin{array}{c}7.09^{\mathrm{Bcd}} \\
\pm 0.07\end{array}$ & $\begin{array}{c}6.95^{\mathrm{Bcd}} \\
\pm 0.08\end{array}$ & $\begin{array}{l}6.72^{\mathrm{Bc}} \\
\pm 0.07\end{array}$ & $\begin{array}{l}6.43^{\mathrm{Bb}} \\
\pm 0.05\end{array}$ & $\begin{array}{l}5.98^{\mathrm{Ba}} \\
\pm 0.06\end{array}$ \\
\hline \multicolumn{7}{|c|}{ Mouth coating } \\
\hline Control & $\begin{array}{l}6.72^{d} \\
\pm 0.07\end{array}$ & $\begin{array}{l}6.65^{d} \\
\pm 0.06\end{array}$ & $\begin{array}{l}6.51^{\mathrm{cd}} \\
\pm 0.07\end{array}$ & $\begin{array}{l}6.30^{c} \\
\pm 0.06\end{array}$ & $\begin{array}{l}6.04^{b} \\
\pm 0.07\end{array}$ & $\begin{array}{l}5.75^{a} \\
\pm 0.09\end{array}$ \\
\hline Treatment & $\begin{array}{l}6.96^{d} \\
\pm 0.06\end{array}$ & $\begin{array}{l}6.86^{d} \\
\pm 0.07\end{array}$ & $\begin{array}{l}6.72^{\mathrm{cd}} \\
\pm 0.07\end{array}$ & $\begin{array}{l}6.50^{c} \\
\pm 0.07\end{array}$ & $\begin{array}{l}6.25^{b} \\
\pm 0.06\end{array}$ & $\begin{array}{l}5.98^{a} \\
\pm 0.06\end{array}$ \\
\hline \multicolumn{7}{|c|}{ Overall acceptability } \\
\hline Control & $\begin{array}{l}7.09^{\mathrm{Ad}} \\
\pm 0.07\end{array}$ & $\begin{array}{c}7.00^{\text {Acd }} \\
\pm 0.06\end{array}$ & $\begin{array}{c}6.84^{\mathrm{Ac}} \\
\pm 0.07\end{array}$ & $\begin{array}{c}6.57^{\mathrm{Ab}} \\
\pm 0.07\end{array}$ & $\begin{array}{l}6.35^{\mathrm{Ab}} \\
\pm 0.05\end{array}$ & $\begin{array}{l}5.79^{\mathrm{Aa}} \\
\pm 0.06\end{array}$ \\
\hline Treatment & $\begin{array}{l}7.11^{\mathrm{Ac}} \\
\pm 0.07\end{array}$ & $\begin{array}{c}7.04^{\mathrm{Ac}} \\
\pm 0.07\end{array}$ & $\begin{array}{c}6.98^{A c} \\
\pm 0.06\end{array}$ & $\begin{array}{l}6.89^{\mathrm{Ac}} \\
\pm 0.06\end{array}$ & $\begin{array}{l}6.51^{\mathrm{Ab}} \\
\pm 0.07\end{array}$ & $\begin{array}{l}6.11^{\mathrm{Ba}} \\
\pm 0.06\end{array}$ \\
\hline
\end{tabular}

Means bearing different superscripts rows wise $(\mathrm{a}, \mathrm{b}, \mathrm{c}, \mathrm{d})$ and columns wise (A, B ...) differ significantly $(\mathrm{P}<0.05)$

Overall acceptability refers to the sensory perception of a meat product in totality. Mean acceptability scores of functional chevon patties remained slightly higher compared to 
control throughout the storage and differed significantly $(\mathrm{P}<0.05)$ on $15^{\text {th }}$ day of storage. Lower acceptability scores in control due to more lipid oxidation and microbial growth during storage. These data are in agreement with Mokhtar et al., (2014) who observed that beef patty samples treated with antioxidants had significantly ( $\mathrm{p}<0.05$ ) higher odour, color, taste and overall acceptability scores than the control. With increasing storage period, mean overall acceptability scores for control was decreased significantly $(\mathrm{P}<0.05)$ from $9^{\text {th }}$ day of storage. However, score for functional chevon patties were not affected significantly $(\mathrm{P}>0.05)$ up to $12^{\text {th }}$ of storage and subsequent storage followed similar trend as control. It might be due to synergistic effect of increasing $\mathrm{pH}$ and microbial load in respective treatment during the storage. Similar observation of decreased overall acceptability scores with increasing storage was reported by Kim et al., (2013) and Nayak et al., (2014) in different meat products.

In conclusion, the developed product was very well accepted up to 15 day under refrigeration. However, thereafter the sensory panelist rejected the acceptability of the products. Moreover, lipid oxidation products and production of ammonia from protein breakdown by microbes may lead to production of off flavor as well significant reduction in saltiness score might be probable cause for poor acceptability of the products by the sensory panelist beyond 15 days. This observation indicated that developed functional chevon patties retained good to very good overall acceptability up to 15 day under refrigeration at $4 \pm 1^{\circ} \mathrm{C}$ in low density polyethylene pouches (LDPE).

\section{References}

A.O.C.S. 1992. Peroxide value acetic acid chloroform method. In: Official methods and recommended practices, firestone D. (Ed.). America Oil chemist Society, Champaign, IL.

A.P.H.A. 1992. Compendium of Methods for the Microbiological Examination of Foods, 2nd edn. Pp. 5-99. Washington, DC: American Public Health Association.

Bhat, Z. F., Kumar, P. and Kumar, S. 2013b. Effect of skin, enrobing and refrigerated storage on the quality characteristics of chicken meat balls. J. Food Sci. Technol. 50(5): 890-899.

Bhat, Z. F., Pathak, V. and Bhat, H.F. 2013a. Effect of refrigerated storage on the quality characteristics of microwave cooked chicken Seekh Kababs extended with different non-meat proteins. J. Food Sci. Technol. 50(5): 926-933

Brian, D. T., Maurice, G., O’Sullivan, R., Hamill, M. and Kerry, J.P. 2012. Effect of varying salt and fat levels on the sensory quality of beef patties. Meat Sci. 91: 460- 465

Chandralekha S., Jagadeesh B. A., Moorthy, S. and Karthikeyan Balakrishnan 2012. Studies on the Effect of Pomegranate Rind Powder Extract as Natural Antioxidant in Chicken Meat Balls During Refrigerated Storage. J. Advanced Vet. Research. 2: 107-112.

Conde, E., Gordon, M. H., Moure, A. and Dominguez, H. 2011. Effects of caffeic acid and bovine serum albumin in reducing the rate of development of rancidity in oil-in water and water-in-oil emulsions. Food Chemistry. 129(4): 1652-1659.

Cremer, M. L. and Chipley, J. R. 1977. Satellite food service system: Time and temperature and microbiological and sensory quality of precooked frozen hamburger patties. J. Food Protection. 40: 603-607.

Das, A. K., Anjaneyulu, A. S. R., Gadekar, Y. P., Singh R. P. and Pragati, H. 2008. Effect of full-fat soy paste and textured 
soy granules on quality and shelf-life of goat meat nuggets in frozen storage. Meat Science. 80: 607-614.

Das, A., Nath, D. R., Kumari, S. and Saha, R. 2013. Effect of fermented bamboo shoot on the quality and shelf life of nuggets prepared from desi spent hen. Vet. World. 6(7):419-423.

Das, S. K., Biswash, S. and Mandal, P. K. 2014. Standardization, Characterization and Storage Stability of Chevon Pithe: A Traditional Indian Meat Cake. Int. J. Meat Sci. 4: 1-14.

Ibrahim, M. A., Salama M. F. and Hussein, A. A. 2011. Production of Functional LowFat Chicken Burger. Australian J. Basic Applied Sci. 5(12): 3149-3154

Jimenez-Colmenero, F. 2007a. Meat based functional foods. In $\mathrm{Y}$. H. Hui (associate Ed.), Chandan et al., (Eds.), Handbook of food products manufacturing (pp. 989-1015). New Jersey: John Wiley and Son, Inc.

Kala, R. K., Kondaiah, N., Anjaneyulu, A.S.R, and Thomas, R., 2007. Evaluation of quality of chicken emulsions stored at refrigeration for chicken patties. Int. J. Food Sci. and Technol. 42: 842-857.

Kandeepan G., Anjaneyulu A. S. R., Kondaiah, N. and Mendiratta, S. K. 2010. Quality of buffalo meat keema at different storage temperature. Afr. J. Food Sci. 4(6):410-417.

Keeton J. T. 1983. Effect of fat and sodium chloride phosphate levels on the chemical and sensory properties of pork patties. J. Food Sci. 48:878-881.

Kim, S., Jin, S.K., Yang, M.R., Chu, G.M., Park, J.H., Rashid, R.H., Kim, I. J.Y. and Kang, S.N. 2013: Efficacy of tomato powder as antioxidants in cooked pork patties. J. Animal Sci. 26(9): 1339-1346.

Koniecko, E.K. 1979. Handbook for Meat Chemists (Chapter 6). Pp. 68-69. New
Jersey, NJ: Avery Publishing Group Inc.

Mohamed, H. M. H. and Mansour, H. A. 2012. Incorporating essential oils of marjoram and rosemary in the formulation of beef patties manufactured with mechanically deboned poultry meat to improve the lipid stability and sensory attributes, LWT- Food Sci. and Technol. 45: 7987.

Mokhtar, Sayed M., Youssef Khaled M. and Morsy Noha E. 2014. The effects of natural antioxidants on colour, lipid stability and sensory evaluation of fresh beef patties stored at $4^{\circ} \mathrm{C}$. J. Agro Alimentary Processes and Technol. 20(3): 282-292.

Nayak, N. K. and Tanwar, V. K. 2004. Effect of tofu addition on physico-chemical and storage properties of cooked chicken meat patties. Indian J. Poult. Sci. 39: 142-146.

Nayak, N. K., Pathak, V., Singh, V. P. and Goswami, M. 2014. Storage study of tofu extended chicken meat nuggets. Indian Vet. J. 91 (11): 42-45.

Nayak, N. K., Tanwar, V. K. and Naruka, S. S. 2006. Cost effective tofu incorporated chicken meat patties. Indian Vet. J. 83(10): 1084-1086.

Nunez de Gonzalez, M. T., Hafley, B. S., Boleman, R. M., Miller, R. K., Rhee, K. S. and Keeton, J. T. 2008. Antioxidant properties of plum concentrates and powder in precooked roast beef to reduce lipid oxidation. Meat Sci. 80:997-1004.

Raharjo, S. and Sofos, J. N. 1993. Methodology for measuring malonaldehyde as a product of lipid peroxidation in muscle tissues: a review. Meat Science. 35 (2): 145-169.

Raja, Waseem Hussain, Kumar, S., Bhat, Z. F. and Pavan Kumar 2014 Effect of ambient storage on the quality 
characteristics of aerobically packaged fish curls incorporated with different flours. Springer Plus 3:106-116.

Ruiz, A., Ayora, M. J. C. and Lendl, B. 2001. A rapid method for peroxide value determination in edible oils based on flow analysis with Fourier transform infrared spectroscopic detection. The Analyst 126: 242-246.

Sahoo, J. and Anjaneyulu, A. S. R. 1997. Effects of natural antioxidants and vacuum packing on the quality of buffalo meat nuggets during refrigerated storage. Meat Science. 47: 223-230

Sibi, G., Chatly, Parul, Adhikari, S. and Ravikumar, K.R. 2012. Phytoconstituents and Their Influence on Antimicrobial Properties of Morinda citrifolia. Research J. Medicinal Plant. 6: 441-448.

Snedecor, G. W. and Cochran, W. G. 1995. Statistical Methods, 8th edn. Pp. 72148. New Delhi: Oxford and IBH Publishing Company.

Sunder, J., Singh, D.R., Jeyakumar, S., Kundu, A. and De Arun Kumar 2011 Antibacterial Activity in Solvent Extract of Different Parts of Morinda citrifolia Plant. J. Pharm. Sci. \& Res.3(8):14041407.

Tapp, W., Nathan, J. W.S., Yanceya Jason, K,. Applea, Michael E., Dikemanb, Richard G. Godbee 2010. Noni puree (Morinda citrifolia) mixed in beef patties enhanced color stability. Meat Science 91: 131-136.

Tarladgis, B.G., Watts, B. M., Younathan, M. T and Dugan, L. R. 1960. A distillation method for the quantitative determination of malonaldehyde in rancid foods. J. American Oil Chemists' Society. 37: 403-406.

Uikey S., Nayak, N. K., Mehta, M. K., Chhabra, D. and Chauhan, L. 2018 Storage Stability of High Fibre: Low Fat Kadaknath Chicken Nuggets Under Refrigeration. International Journal of Microbiology Research, 10 (10): 13821386.

West, B. J., Deng, S. and Jensen, C. J. 2011. Nutrient and phytochemical analyses of processed noni puree. Food Research International. 44: 2295-2300.

\section{How to cite this article:}

Nayak, N.K., V. Pathak, M. Goswami and Bharti, S.K. 2019. Shelf Life Assessment of Functional (Antioxidant Added Low Fat-Low Sodium) Chevon Patties under Refrigeration. Int.J.Curr.Microbiol.App.Sci. 8(06): 875-889. doi: https://doi.org/10.20546/ijcmas.2019.806.106 